\title{
Cultural citizenship, political belonging, and the European Union*
}

\author{
John McCormick \\ Indiana University
}

\begin{abstract}
Summary: I. Introduction. - II. A European political culture?III. The effects of Parliamentary Government. - IV. Conclusions.
\end{abstract}

\begin{abstract}
Like many concepts in the social sciences, the notion of citizenship is subject to different understandings based on the particular interests and preferences of those who engage in public discourse about its meaning. The particular notion of EU citizenship is often dismissed as insubstantial. Authors note that EU member states continue to have different laws on citizenship, that Union citizenship is derived from member state citizenship, and that Union citizenship has failed to promote much of a sense of European identity. The particular idea of cultural citizenship, meanwhile, has been described by some as an oxymoron, with many authors noting that while it is a useful concept, it remains underdeveloped and underemployed, and that it needs to be further articulated in connection with specific issues and contexts. This paper will attempt to do just that by moving from theory to practice, exploring ways in which ideas of political and cultural belonging have overlapped in such a way as to direct citizenship in Europe away from an association with states or cultures to an association with ideas.
\end{abstract}

Keywords: Union citizenship, European identity.

Resumen: Como muchos conceptos en las ciencias sociales, la noción de ciudadanía está sujeta a diferentes interpretaciones basadas en los intereses y preferencias particulares de aquellos que participan en discursos públicos sobre su significado. A menudo se descarta la noción de ciudadanía de la Unión Europea como insustancial. Distintos autores constatan que los Estados miembros de la Unión Europea continuan teniendo diferentes leyes sobre la ciudadanía, que la ciudadanía de la Unión se deriva de la ciudadanía de los Estados miembros, y que la ciudadanía de la Unión no ha sido capaz de promover un sentido de identidad europea. La idea de ciudadanía cultural, mientras tanto, ha sido descrita como un oximorón, y muchos autores opinan que si bien se trata de un concepto útil, sigue estando muy poco desarrollado y muy poco utilizado, y que necesita ser articulado en conexión con temas y contextos más específicos. En esta misma línea, partiendo de la teoría hacia la práctica, este artículo pretende explorar cómo ciertas ideas de pertenencia política y cultural se han solapado de tal manera que están dirigiendo a la ciudadanía en Europa desde la asociación con Estados o culturas hacia una asociación con ideas.

Palabras clave: Ciudadanía de la Unión, identidad europea.

* Recibido el 31 de noviembre de 2012, aceptado el 20 de diciembre de 2012. 


\section{Introduction}

Where citizenship has long been understood and discussed in formal civil and legal terms, and its cultural qualities have often been overlooked, the growing racial and religious diversity of Western societies since the end of World War II has generated a new interest among scholars in the relationship between diversity and equity. The concept of cultural citizenship has been developed as a supplement to traditional ideas about political citizenship, the suggestion being that citizenship needs to be inclusive enough to allow for the cultural differences that exist within and among states. It is thus a question, as Rosato puts it, of 'who needs to be visible, to be heard, and to belong', or the recognition, as Touraine puts it, of the existence of new political spaces where 'minorities' are protected and intercultural exchanges are promoted. ${ }^{2}$ Another definition suggests that cultural citizenship 'concerns the ways in which various groups such as immigrants, religious groups, women and minorities use cultural practices to stake identity and citizenship claims. It is about the quest for cultural belonging, being counted and being heard in an increasingly globalized world.' 3

Delanty and Rumford regard the differences among European cultures both as positive and as a possible first step in the process of building a European citizenship; in other words, they argue, European identity 'might be seen as the recognition of differences and the capacity to build upon them' ${ }^{4}$ At the same time, Habermas suggests that the notion of cultural citizenship raises the demand for a revised model of the public sphere. ${ }^{5} \mathrm{He}$ and Jacques Derrida hailed the birth of just such a sphere on 15 February 2003 in the wake of mass demonstrations in almost every European capital against the impending US-led invasion of Iraq. They spoke of Europe now having its own 'political mentality' exemplified by support for notions such as secularism, welfarism, and multilateralism. ${ }^{6}$

${ }^{1}$ ROSALDO, R., "Cultural Citizenship, Inequality and Multiculturalism”, in TORRES, R.D. et alter (eds.), Race, Identity and Citizenship, Blackwell, Oxford, 1999.

2 TOURAINE, A., Can We Live Together? Equality and Difference, Polity Press, Cambridge, 2000.

3 Center for Cultural Citizenship, University of New Hampshire, at http://www.unh.edu/ humanities-center (last retrieval on September 2012).

${ }^{4}$ DELANTY, G. and RUMFORD, C., Rethinking Europe: Social Theory and the Implications of Europeanization, Routledge, London, 2005, p. 63.

5 HABERMAS, J., The Structural Transformation of the Public Sphere, Polity Press, Cambridge, 1989.

${ }^{6}$ HABERMAS, J. and DERRIDA, J., "February 15, or What Binds Europe Together: Plea for a Common Foreign Policy, Beginning in Core Europe", in Frankfurter Allgemeine Zeitung, 31 May 2003. Reproduced in LEVY, D. et alter (eds.), Old Europe, New Europe, Core Europe, Verso, London, 2005. 
Three points are worth making about the debate over cultural citizenship. First, the bulk of the literature comes out of the disciplines of history, sociology, anthropology, and philosophy, or has been written by those with an interest in literature or other forms of expression. Political considerations have to date been included only in a marginal sense, and political scientists have contributed relatively little to the debate. Second, the bulk of the literature is notable for its failure to define cultural citizenship as a concept. By no means is this an unusual state of affairs; it is quite normal within the social sciences to debate concepts without agreeing how they are best defined, or to employ contrasting definitions. This leads to the third point, which is that there seems to be a consensus that the idea of cultural citizenship is something of an oxymoron, and that while useful, it remains underdeveloped and underemployed, and needs to be further articulated in connection with specific issues and within more particular contexts.

If cultural citizenship is concerned with the role of culture in citizenship, and is concerned with notions of recognition, empowerment, and common experiences, then political considerations should clearly play a central role in our efforts to pin down its meaning. This is particularly true of Europe and European integration; the latter is often dismissed by its critics as having failed to generate a sense of belonging, and questions are often asked about the seeming absence of a sense of European identity, or of an understanding of what Europe represents, and there is even conjecture regarding the death of multiculturalism in the European context. But while much of the literature on cultural citizenship focuses on minorities, it could be argued that within the context of the EU, containing as many nationalities as it does, all Europeans are members of minority groups. The issue, then, may be less one of how they are recognized than of how or whether they have been able to rise above narrow political values and agendas, and how far we might be able to identify a European political space.

This article sets out to address criticisms of the underdevelopment and underemployment of the idea of cultural citizenship by looking at its political dimensions in the context of the European Union. But rather than pursuing the idea that cultural citizenship might be a means through which minorities use cultural practices to stake identity and citizenship claims ${ }^{7}$, it turns the notion on its head by arguing that ideas of political and cultural belonging have overlapped in such a way as to direct citizenship in Europe away from an association with states or cultures to an association with ideas. Specifically, it argues that there are clear indications of the emergence

7 Center for Cultural Citizenship, University of New Hampshire, at http://www.unh.edu/ humanities-center (last retrieval on September 2012). 
of a shared political culture in the European Union (and in Europe more broadly) whose existence represents a pooling of political values through which the interests and concerns of minorities have become subsumed within a broader idea of what Europe represents in political terms. In other words, where Miller begins his 2007 study of cultural citizenship with the observation that "wwe are in a crisis of belonging', this article suggests that there is a distinctively European political space whose features - if more widely understood and recognized-would obviate many of the concerns about belonging.

\section{A European political culture?}

The notion of cultural citizenship can be traced back to a seminal 1964 article by $\mathrm{T} \mathrm{H}$ Marshall in which he outlined the expansion of citizenship from civil through political to social rights. ${ }^{9}$ The civil component included 'liberty of the person, freedom of speech, thought and faith, the right to own property and to conclude valid contracts, and the right to justice'. The political component involved 'the right to participate in the exercise of political power'. The social component entitled citizens to live the life of a civilized being according to the standards prevailing in the society".

The definition of citizenship was subsequently expanded, primarily in the work of Turner, to include culture. ${ }^{10}$ Cultural rights, argues Pakulski, 'include rights to unhindered and dignified representation, as well as to the maintenance and propagation of distinct cultural identities and lifestyles'. ${ }^{11}$ He goes on to suggest that while the concept of cultural rights is not new, it has rarely been linked to citizenship, and that it might be seen as a new set of citizenship claims involving 'the right to symbolic presence and visibility (vs. marginalization); the right to dignifying representation (vs. stigmatization); and the right to propagation of identity and maintenance of lifestyles (vs. assimilation)'. Full cultural citizenship, he concludes, is seen less as a matter of legal, political and socioeconomic location so much as a matter of symbolic representation, cultural-status recognition and cultural promotion.

${ }^{8}$ MILLER, T., Cultural Citizenship: Cosmopolitanism, Consumerism and Television in a Neoliberal Age, Temple University Press, Philadelphia, PA, 2007, p. 1.

9 MARSHALL, T.H., Class, Citizenship and Social Development, Doubleday, New York, 1964.

10 TURNER, B.S., Citizenship and Capitalism: The Debate over Reformism, Allen \& Unwin, London, 1986; TURNER, B.S., "Outline of a theory of citizenship", in Sociology no. 24, 1990, pp. 189-214; TURNER, B.S., "Contemporary problems in the theory of citizenship", in TURNER, B.S. (ed.), Citizenship and Social Theory, Sage, London, 1993.

11 PAKULSKI, J., "Cultural citizenship", in Citizenship Studies 1:1, 1997, pp. 73-86. 
To discuss cultural citizenship in the European context is to suggest that minorities are marginalized and stigmatized, and that their separate identities are insufficiently recognized. There has been much discussion of late about the alleged failure of multiculturalism in Europe, but closer study reveals that this failure is discussed more in terms of the failures of multiracialism and of tolerance for Islam. In regard to culture as such, Europe has long been multicultural and while there has been integration taking place at the macro level, the rights of national and cultural minorities have been increasingly recognized to the point where a process of disintegration (or, at least, the assertion of rights) has set in at the micro level. At the same time, however, Europeans share much in regard to the collective norms, values and attitudes that govern the expectations of society about politics and government; in regard, that is, to political culture, if this term is understood along the lines proposed first by Durkheim, and then developed by Almond and Verba. ${ }^{12}$ In other words, there are common themes in the way that Europeans believe that government should be conducted, in the role they feel that government should play in their lives, in the role they see themselves playing in the political process, in their views regarding the core purposes of government, and in their views regarding the political goals and ideals of society.

Surprisingly little has to date been proposed along these lines, which is less an indication that such themes do not exist than a reflection of the limited perspective of most political scientists: comparativists tend to see Europe as a collection of sovereign states, and have paid little attention paid to the idea that there might be a European political space separate from - or in addition to-those of the EU or its individual member states. Meanwhile, the long domination of political studies of the EU by scholars of international relations means that the EU has only recently begun to be seen as a political system in its own right. Rather than a European political culture, then, what most scholars of Europe see is a constellation of national political cultures. The effect of this is to draw discussions into the question of how minority interests and rights can be recognized and protected (in other words, into the question of how cultural citizenship applies in the European context) when it might be argued instead that a closer understanding of the features of European political culture would indicate that minority interests and rights are already recognized and protected through the influence they have had on shaping that political culture.

12 DURKHEIM, E., The Division of Labour in Society, Macmillan, Toronto, 1933; ALMOND, G.A. and VERBA, S., The Civic Culture: Political Attitudes and Democracy in Five Nations, Princeton University Press, Princeton, NJ, 1963, and The Civic Culture Revisited, Little, Brown, Boston, 1980. 
There are at least five qualities that make European political culture distinctive. First, Europeans have a singularly pragmatic view of the nature, purposes, and possibilities of democracy, driven by their historical experiences and by their views about the nature both of civil society and of the mechanics of today's relationships between and among European states. They are restrained in how much they believe can be achieved without both the necessary combination of time, effort, political will, and good fortune. This might be described as pessimism, but it might also be regarded as realism or pragmatism given the limitations of achieving change within complex political and social arrangements. The views of Europeans are reflected in the extent to which they place a premium on results over rules and in ensuring that the results are as equal as possible. The European experience stands in contrast to that of the United States, where-at least until the recent economic downturn - there is more of a focus on aspirations, possibilities, and achievement of the American Dream, which assumed in part that life for each generation will be better than for the previous generation .

Second, patterns of political participation in Europe have been changing, with a drift away from the conventional and towards the unconventional. The data show that participation in the electoral process has been declining through much of Europe, with fewer people engaging in campaign activities, and turnout at national elections either falling or remaining static. The most common explanation for this has been a growing sense of political alienation, but it may simply be that Europeans are rejecting indirect participation in politics through their elected officials - in whom they generally have declining trust and faith-in favour of more direct influence through interest groups, referendums, petitions, or direct political action. There has, in other words, been something of a shift from representative democracy to participatory democracy in Europe..$^{13}$

Third, the dynamics of European integration have helped promote a culture of compromise and consensus decision-making. Making policy at the European level has meant involving more people and interests in a decision, taking into consideration a greater variety of opinions and agendas, and thereby slowing down the decision-making process. This can be frustrating, and in the case of the response to the crisis in the euro zone it has been stretched and tested, but it is also the essence of democracy. The consensual qualities of the European project stand in contrast to the United States, which is often congratulated for its democratic achievements but has become so polarized of late-thanks mainly to its two-party political

13 ALMOND, G.A. et alter (eds.), European Politics Today, 2nd ed, Longman, New York, 2002, pp. 42. 
system, the capture of its politicians by special interests, and the tendency of elected representatives to look only to their core base of support-that many worry about its ability to address its manifold problems. Europeans are more familiar with coalition government, which can be slow and unstable but is more inclusive and requires more compromises. In this sense, the EU model is a natural outgrowth of the coalitions that are the norm in most of its member states.

Fourth, government in Europe is attuned to the needs and procedures of international (actually, inter-state) decision-making. While this is generally true of all governments that engage in the work of international organizations, that ratify international treaties, and that take seriously their obligations under international law, with Europeans this phenomenon has evolved further. The obvious explanation can be found in the patterns of cooperation that have been required under EU decision-making, where the independence of national governments has been reduced in favour of broader European interests. Less obvious, however, has been the impact of changing views about the role of the nation and the state, and the growing hold of cosmopolitanism on the Europeanist political imagination. While much is made of the difficulties that European governments have experienced in finding common ground on numerous issues, the existence of a substantial body of European law and policy attests to the extent to which a consensus has been achieved. It also illustrates the extent to which national interests have been combined with and often subsumed under European interests, and the extent to which the European governing style combines local, national, state and European interests.

Finally, if there is one particularly distinctive quality of political culture in Europe it is support for communitarianism. Europeans believe that there has been too much emphasis on individual liberty and too little on the community, and that there should be more of a balance between individualism and social responsibility. ${ }^{14}$ Selznick defines communitarianism as 'any doctrine that prizes collective goods or ideals and limits claims to individual independence and self-realization'. ${ }^{15}$ Etzioni sees it as a concern with 'the balance between social forces and the person, between community and autonomy, between the common good and liberty, between individual rights and social responsibilities'. Communitarians, he argues, are not majoritarian, but instead seek a 'strong democracy' in which activity goes beyond occasional political participation, and government is instead responsive to all its members. Each member of the

14 See ETZIONI, A., The Spirit of Community: Rights, Responsibilities and the Communitarian Agenda, Fontana Press, London, 1995.

15 SELZNICK, P., The Communitarian Persuasion, The Johns Hopkins University Press, Baltimore, MD, 2002, p. 4. 
community owes something to all others, and the community owes something to each of its members. ${ }^{16}$ On the economic front, communitarians argue that the debate between supporters of the private sector and the public sector has overlooked the needs of society.

Communitarianism has been described by its critics as 'anti-individual' ${ }^{17}$, and some of its critics may quote Abraham Lincoln's argument that prohibition runs the danger of making a crime out of something that is not a crime. But this rather misses the point regarding the way it is approached by Europeans, who are more likely to argue that a decent society is based less on rights than on duties, and that for the opportunities provided by society, individual responsibility is demanded. Communitarianism underpins attitudes towards social welfare in Europe but it is also a defining part of the manner in which Europeans approach government: they would argue that society can be a better judge of what is good for individuals rather than vice versa, and that the state has a role in restricting individual rights for the greater good of the community. In other words, while they support negative rights, they are more willing to allow the state to take action on individual issues in the interests of the community.

The emphasis here is on the state rather than on government, in which Europeans have low levels of faith and trust (but no lower than those in other liberal democracies ${ }^{18}$ ). Polls in the EU indicate that levels of trust in the army, the police and the media are significantly higher than those in government institutions and political parties. Few believe that national administrative institutions are transparent (68 per cent believe they are not very transparent or not transparent at all, compared to 24 per cent who believe they are very transparent or transparent), and in spite of doubts about integration-which have worsened markedly in the wake of the euro zone crisis-Europeans do not make much of a distinction between the problems faced by their country, by the EU, and by the world; majorities of 58 per cent, 55 per cent and 54 per cent respectively feel that each is headed in the wrong direction. ${ }^{19}$ Polls also indicate higher levels of trust in voluntary organizations, reflecting the extent to which Europeans are willing to replace political engagement with civic engagement.

16 ETZIONI, A., "Introduction", and "The Responsive Communitarian Platform: Rights and Responsibilities", in ETZIONI, A. (ed.), The Essential Communitarian Reader, Rowman and Littlefield, Lanham, MD, 1998, p. x, p. xix.

17 FRAZER, E., The Problems of Communitarian Politics: Unity and Conflict, Oxford University Press, New York, 1999, p. 21.

18 BLIND, P.K., "Building Trust in Government in the Twenty-First Century: Review of Literature and Emerging Issues". Paper presented to 7th Global Forum on Reinventing Government, Vienna, 2007.

19 EUROPEAN COMMISSION, Eurobarometer 76, autumn 2011, p. 37. 


\section{The Effects of Parliamentary Government}

In addition to these general features of political culture in Europe, it is important also to better understand the structure of political institutions and the role they might play in encouraging cultural citizenship. Are political institutions a reflection of the culture in which they are embedded, or are cultures a reflection of the character of their governing political institutions? In other words, to what extent do the structural principles of institutions reflect or shape the political cultures of the societies in which they function? The evidence suggests that there is a symbiotic relationship at work, with both elements shaping and being shaped by the other. Of one principle we can be sure: the relationship is never static, and new challenges, needs and opportunities bring constant change in the internal organization of institutions, in their relationship to one another, and in their place within the political system. ${ }^{20}$

The one relative constant in the European case has been the durability of the parliamentary model, which was born and bred in Europe, and is today used in one form or another in every European state. It has been exported outside Europe, to be sure, and we may not be able to claim that it is any longer uniquely European, but nowhere does it dominate national government to the same extent, or provide politics and government with quite so strong an institutional identity or quite so distinctive a procedural character, as it does in Europe. The region remains - in the view of Müller et al - 'the heartland of parliamentarianism'. ${ }^{21}$ The parliamentary model has four core elements and effects.

- The co-existence of a political head of government and a symbolic head of state.

- The fusion of executive and legislature; the former comes out of - latter, and the two have mutual sets of responsibilities to - and powers over - the other.

- Collective decision-making through a cabinet or council of ministers.

- The division of parliament into governing and opposition parties or coalitions.

First, with the exception of states using the semi-presidential or dual executive model, a political head of government and a symbolic

${ }^{20}$ For discussion, see HALL, P.A., "Institutions and the Evolution of European Democracy", in HAYWARD, J. and MENON, A. (eds.), Governing Europe, Oxford University Press, Oxford, 2003.

${ }_{21}$ MÜLLER, W.C. et alter, "Parliamentary Democracy: Promise and Problems", in STRØM, K. et alter (eds.), Delegation and Accountability in Parliamentary Democracies, Oxford University Press, Oxford, 2006, p. 4. 
head of state co-exist. This encourages the view that allegiance to the state is not necessarily the same as allegiance to the government, and vice versa. Heads of government come and go, their position and power dependent upon changing levels of public support and approval, but the head of state remains as the embodiment of the values of the state, largely untouched (except in semi-presidential executives) by ideological partisanship. The situation in Europe stands in contrast to that found in executive presidential systems such as the United States, Mexico, Brazil, or Argentina, where the combination of political and state responsibilities in a single office blurs the distinction between allegiance to state and allegiance to government.

Monarchies and non-executive presidents offer Europeans several advantages: they provide an institution that functions above politics and around which the citizenry can rally in times of trouble, they can arbitrate the formation of a new government should there be no party or coalition in clear control of a legislature, they can act as a moral constraint on elected political leaders attempting to extend their powers, and they can act as politically-neutral symbols of the state that represent the interests of its multiple cultures and minorities. Legitimation can be provided by constitutions and courts, it is true, but the process of judicial review is often politically charged, and judges will often have their own political agendas. This is rarely the case with monarchs or non-executive presidents in the European model. At the same time, however, non-executive heads of state are often criticized for being expensive symbols, and monarchs in particular are rejected by republicans as a throwback to the feudal era, as perpetuators of the class system, and as dividers rather than uniters. In today's increasingly egalitarian Europe, however, where monarchs are expected to show the common touch, the socially and culturally divisive nature of monarchs and their attendant aristocracies has declined.

The second quality of the parliamentary model is that it fuses executive and legislative functions. The prime minister is normally the leader of the biggest political party in the legislature, or the individual most acceptable to the parties joined in a coalition government. Thus the executive is closely identified with the balance of parties in the legislature, and prime ministers are themselves members of the legislature; there is typically no separate election for a prime minister. Prime ministers have extensive powers of appointment, and are rarely required to have their appointments confirmed by another body. They also have strategic advantages tied to their control of the party or coalition, and to their ability to decide the date of national elections. Decision-making within the cabinet is collective, but the prime minister coordinates, sets the agenda, and expects the support of cabinet colleagues. Governments with strong majorities in the legislature can also 
normally expect party unity, meaning strong influence over the legislative programme. The effect of this is to make the lines of policy responsibility relatively clear.

By contrast, an executive or semi-executive president may have to govern in conjunction with a hostile legislature, particularly when the opposition has a majority, but even in some cases when the president's own party has a majority. In the parliamentary system, partisanship is normal, party discipline is relatively tight, and lines of responsibility are more clear. In a presidential republic or a semi-presidential system, the links between the executive and the legislature are not as strong, mainly because the president does not control key appointments within the legislature. As a result, partisan lines are more blurred, and there is less association between voters and parties. There is also more opportunity for legislatures to block the policy programme of the executive (an event that would potentially set off a crisis or even a fall of the government in a parliamentary system), and for the executive to blame a hostile legislature for its own failures. Hence the lines of responsibility are often less clear.

The third effect of the parliamentary model is that cabinet government is at the heart of the European political process. ${ }^{22}$ As well as governing collectively, and being the foundation of the power and influence of the prime minister, cabinets (or councils of ministers) are also testing grounds for future contenders for the prime ministership, and a vital link between the bureaucracy, the government, interest groups, and voters. Members of the cabinet are usually members of the legislature, and the cabinet as a whole is politically responsible to the legislature, which has the power of oversight over ministers and their departments, and can compel the cabinet to resign. Cabinet government is by no means unique to Europe, and is found in some form in parts of Africa and Asia, but nowhere is it so generalized or so much a feature of the process of government as in Europe.

Finally, the dynamics of the European parliamentary model are based fundamentally on the centrality of political parties to the political process. The prime minister and cabinet rely on the majority party or coalition as the base of their support and power, and for security of tenure. In majoritarian systems ${ }^{23}$ where large parties sometimes dominate, such as those in

22 See BLONDEL, J. and MULLER-ROMMEL, F. (eds.), Cabinets in Western Europe, 2nd ed., Palgrave Macmillan, Basingstoke, 1997, and Cabinets in Eastern Europe, Palgrave Macmillan, Basingstoke, 2001; STRØM, K. et alter (eds.), Cabinets and Coalition Bargaining: The Democratic Life Cycle in Western Europe, Oxford University Press, Oxford, 2008.

${ }^{23}$ For discussion of the majoritarian/consensual dichotomy, see LIJPHART, A., Patterns of Democracy: Government Forms and Performance in Thirty-Six Countries, Yale University Press, New Haven, CT, 1999. 
Britain, Ireland, France and Greece, the executive can wield considerable powers and is almost guaranteed that its policies will be confirmed by the legislature. But this is relatively rare. More typically in Europe, there are multiple parties representing the entire political spectrum, from communists and socialists on the left through greens, social democrats, centrists and liberals to Christian Democrats, conservatives, and fascists on the right, along with regional parties in many countries. The result is that coalitions have become the norm, particularly in the Benelux countries, Scandinavia, Germany, Italy, Ireland and Switzerland. Whether these are coalitions of the centre-left or the centre-right, the number and variety of their membership results in a system in which parties are typically obliged to cooperate and compromise in order for business to be done.

Another quality of party politics in Europe is the critical role played by parties in defining and mobilizing opposition. In executive presidential systems, parties do not always typically function as the formal opposition, mainly because they do not have leaders in place who would take over the presidency were the party to win a majority at an election. In authoritarian systems such as China or many African states, opposition parties are either not permitted or are controlled and manipulated. But in Europe, opposition parties are a central and formal part of the political process, help clarify the political options for voters, and play a critical role in determining the structure and longevity of governments.

There has been much debate over the last few decades about the decline of European party systems, and even about periodic crises in that system. But while it is clear that parties may not always have as much power as they think they do, and that party systems constantly evolve, they continue to persist, and it is hard to imagine what would replace them. ${ }^{24}$ Furthermore, while legislatures and courts in particular have lost some of their powers as a result of the twin effects of European integration and regional devolution, the same cannot be said for parties. Integration has been slow to impact national parties ${ }^{25}$, but the creation in recent years of a growing number of pan-European party confederations promises to bring national parties closer together, and to encourage them to run pan-European campaigns for elections to the European Parliament, giving them a more prominent role in pan-European politics. Meanwhile, rising support for devolution and national self-determination has injected new vitality into national party

${ }^{24}$ See discussion in SMITH, G., "The Decline of Party?" in HAYWARD, J. and MENON, A. (eds.), Governing Europe, Oxford University Press, Oxford, 2003.

${ }^{25}$ See discussion in MAIR, P., "The Limited Impact of Europe on National Party Systems", in GOETZ, K.H. and HIX, S. (eds.), Europeanised Politics? European Integration and National Political Systems, Frank Cass, London, 2001. 
systems by both encouraging the creation of new regionalist parties and obliging national parties to develop policies on regionalism.

\section{Conclusions}

This paper began by reiterating the point that the concept of cultural citizenship has been developed as a supplement to traditional ideas about political citizenship, based on the suggestion that citizenship needs to be inclusive enough to allow for the cultural differences that exist within and among states. This is clearly of importance and relevance to better understanding the modern European experience, given the variety of states and cultures within the European Union specifically and Europe more broadly. But rather than approaching cultural citizenship as a means through which minorities could use culture to stake claims to identity, the paper goes on to argue that the interests and concerns of minorities have been critical to defining the broader identity and meaning of Europe. Within Europe there are no majorities, thus everyone is a member of a minority of one kind or another, and European identity is based on the foundation of bridging those differences.

Critical to this discussion has been the possibilities of the emergence of European political space, driven by the emergence of a shared political culture in the European Union (and in Europe more broadly). In other words, rather than the EU witnessing a crisis of belonging (the core idea behind most discussions about cultural citizenship), the paper suggests that there is a distinctively European approach to politics whose features would indicate the growth of a sense of belonging in Europe, regardless of national or cultural background. The effect, then, has been to allow minorities to drive the establishment of shared approaches to the manner in which government is conducted, to the roles expected of government, to the roles of citizens in the political process, to the views of citizens regarding the core purposes of government, and to a European definition of the political goals and ideals of society. In short, the process of European integration has led to an overlap of ideas about political and cultural belonging, directing ideas about citizenship in Europe away from an association with states or cultures and towards an association with ideas, in this case of a political cultural nature. 